\title{
Achieving Sustainable Competitive Advantage of Romanian Rural Area by Integrating Information Technologies: an Interdisciplinary Approach
}

\author{
Răzvan Sorin ŞERBU, Sorin BORZA \\ "Lucian Blaga" University of Sibiu, \\ 10, Calea Dumbravii, Sibiu, 550024, Romania, \\ razvan.serbu@ulbsibiu.ro,sorin.borza@gmail.com
}

\begin{abstract}
The Information and Communication Technologies and digital economy are the key factors in the recovery of the EU economy and especially the Romanian economy. Based on its strengths in technology and knowledge, Europe should exploit the full potential of the digital economy. The digital economy and information technologies offer great opportunities for SMEs in the manufacturing and service sectors. Therefore, an ambitious Digital Agenda, providing concrete steps to complete the online single market will be a key to sustainable economic recovery and social development of Europe. The competitive advantage of each country will play an important role in sustaining its future prosperity. Information technologies offer new ways of enhancing sustainable development not only in urban areas but also, to an even greater extent, in rural areas throughout the world. The understanding of what makes them a success or failure, and how much impact they may have in contributing to the wider rural economy is still relatively poorly developed. What is clear, from a wider European perspective, is that these new forms of e-agriculture with ecological entrepreneurialism are growing at a relatively fast rate This paper presents multi-criteria AHP method, (Analytic Hierarchy Process) to assess main technological factors that affect the introduction of new technologies in rural areas.
\end{abstract}

Keywords: e-agriculture, digital economy, eco-bio-economy, competitiveness multicriterial.

\section{Introduction}

\begin{abstract}
Aims
Given the potential for additional growth this represents, a more thriving EU services sector which is a priority for the European Commission, as services are regarded as the driving force of the EU economy and statistics show that around nine out of ten new jobs are created in this sector. As identified in the Commission's Annual Growth Survey, the EU will only meet its ambitious Europe 2020 targets for sustainable and inclusive growth if urgent structural reforms are prioritized in services and product markets to improve the business environment [1].
\end{abstract}

eEurope, eEurope+ (plan dedicated to countries in the adhesion process - before the enlargement of the European Union), eEurope 2005, i2010, i2020 Strategy action plans have represented major measures in developing the IT\&C infrastructure in Europe, citizen education, developing the ability to use new technologies, launching new concepts meant to contribute in the development of the European economic society: e-Government, e-Health, eLearning, e-Inclusion, etc.) [2].

We are focusing here on opportunities for a sustainable development and grow in competitiveness in rural area of nowadays, based on the implication of digital economy and Information and Communication Technologies initiatives in rural sector, presenting and discussing latest research and suggesting new ideas, solutions and methods for sustainable producing food, natural resource management, building resilient agricultural systems and farming systems from a bio-ecoeconomic perspective.

In this tough time of financial and economic crises, the potential of rural area should be more and more shifted into consideration. The timeliness that is going to be recorded for integrating the information technologies into the rural area will create a competitive advantage. This can make the difference between nations and one can gain advantage against the others world's best competitors.

National prosperity is created, not inherited. It does not grow out of a country's natural endowments, its labor pool, its interest rates, or its currency's value, as classical economics insist. A nation's competitiveness depends on the capacity to innovate and upgrade [3].

Following the dynamism of nowadays we consider an essential condition for harmony the possibility for economic discipline to enlarge its sphere of investigation. In this order, besides the current preoccupation with mathematic models and statistical analysis it should take care of the great importance but too little 
analysed so far such as anthropology, morale and eco and bio economy.

The last decades have called the public attention and decision makers towards a new dimension, the ecological one. By minimizing the consequences of our actions the way man has behaved is being explained as well as the way he was supposed to be compared to the world he lives in and the other life forms he depends on, directly or indirectly through food or other needs.

Therefore as biological beings our activities directed towards the satisfaction of our own needs as being the only ones to be taken into consideration are justified even if they lead to self-destruction.

\section{Background}

Eco Bio Economy can be considered an attempt for a new economic vision that reunites: economy, ecology, biodiversity, eco economy and bio economy and it is focused on the intelligent sustainable development of the world.

Recently in the international literature of specialty are more attempts to unite the two concepts in a new paradigm the ecoeconomy from Lester Brown and the bioeconomy from Georgescu Roegen.

Eco Bio Economy defined as such: it is an economy of the future is the life of people by using the environment resources rationally. (bios meaning "life" and "oikos" meaning "habitat" in Greek language). It can create "arenas and reflection spaces in specialist researchers and experts in different, domains but in some other domains insufficiently explored so far". Eco Bio Economy can generate new directions to approach: Eco Bio Sanogenesis, Eco Bio Ethics, Eco Bio Engineering and new conceptual directions: Eco Bio Projects and Eco Bio Concepts [4].

The Eco Bio Vision of Economy is to develop the welfare of the mankind under all forms in a sustainable way through an economy of the future for people's life by using the environment resources rationally. Eco Bio Economy is a scientific attempt; an economic and philosophic one dedicated to the development of environmental interpreted health, of the welfare of humanity through a concept that is multipolar interpreted and promotes the Agrifood Green Power and Smart Sustainable Integrated Development of future
[5]. All of this can be and should be integrated with the new wave of digital economy.

Paul Hawken in his paper "Blessed Unrest" comes to the conclusion "Now we steal our future by selling it and by calling it G.D.P." We could have an economy of improvement for the future instead of stealing. One is called reconstruction the other manoeuvre [6]. This new e-economy, that anyone is expected, it will work only if we will understand the importance of right integration of digital economy in all sectors of life, and we are referring in these lines especially to agricultural aspect.

The mobile phone is being used mostly in the rural area (86\%) than in the urban one $(77 \%)$ in order to keep in touch with those who are abroad and the age of those who useit are under 60 years old. Approximately $3 / 4$ of the Romanians are using this service and $80 \%$ of the clients currently use a single SIM.GfK Romania made a study on the habits to use the internet in Romania along a period of two years - 2010 to 2012. The results point out that the incidence with persons aged 15 and more was of $48.7 \%$ in 2012 , increasing with $8.4 \%$ as compared to 2010 .

The rate of entering in households regarding retransmission services increases with $4 \%$ to $85,1 \%$, and the rate through cable networks arrives at $53,6 \%$.

At the end of the year 2012, 61\% of the subscribers lived in the urban area. According to the retransmission $80 \%$ of the users in the urban area are subscribers for the cable while $63 \%$ of the users in the rural area are subscribers for satellite networks of DTH type.

The number of the subscribers for cable networks increased with $6,4 \%$ to 3,8 mil. Of which the number of those who have access to such services of digital format registered an increase with 40 to 1,24 million subscribers.

Therefore, the share of the number of subscribers through digital networks within the total number of subscribers through cable was of almost $33 \%$ at the end of 2012 .

Retransmission services of programs in a digital format continued to increase in 2012 and the subscribers for such services are increasing according to ANCOM.

Of six million subscribers to retransmission services, 3,4 million are being subscribed for 
services in a digital format, increasing with $13,4 \%$ as compared to 2011 .

Of the number subscribers for services in a digital format $63 \%$, is being held by the subscribers though satellite (DTH) but, in genuine figures, the increase in 2012 was registered by the cable subscribers in a digital format. After the decrease registered in 2011 the number of DTH subscribers increased last year with $2 \%$ to 2,19 mil. subscribers, and those through the IP(IPTV) technology increased with $34 \%$ for 37.000 subscribers.

\section{AHP (Analytic Hierarchy Process)}

Multicriterial evaluation in new technologies is used in cases where there are several alternatives, variations, locations or processes. The common result of multicriterial evaluation methods is a dimensionless number that indicates the degree of new technologies load of alternatives that are evaluated. In addition to indicators that represent the new technologies impact it is possible to include indicators that have economic, social, and technological character. The paper describes one method of multicriteria analysis, analytic hierarchy process (AHP). Presented example gives application of multicriteria analysis in evaluating new technologies factors. Multicriteria analysis was conducted on six new technological factors: TV subscriptions, mobile phones number, fixed phone subscriptions number, Internet subscriptions. This method is used to determine which of the factors listed above is the most important in the impact of new technologies on rural areas[7].

Analytic Hierarchy Process (AHP) is used for decision making when a decision (choice of some of the available alternatives, or their ranking) is based on several attributes that represent criteria. Solving complex decision problems using AHP method is based on their decomposition in a hierarchical structure whose elements are goal (objective), criteria (subcriteria) and alternatives. An important component of the AHP method is a mathematical model by which priorities of elements are calculated (weighted), for elements that are on the same level hierarchical structure [8]. AHP was successfully used in new technologies impact assessment for determining of weights for impact categories.

Summary of AHP method consists of converting subjective assessments to the relative importance of the criteria scores and weights. The method, developed by Saaty [9], proved to be the most common form of multicriteria analysis. AHP input data are answers to questions such as "How important is criterion A relative to criterion B?". This results are compared in pairs, resulting are in scores and weights. For each pair of criteria required comparing the importance of the two, associating a score as follows.

Table 1.The comparison of each pair for criteria required

\begin{tabular}{|c|c|}
\hline Definition & $\begin{array}{c}\text { Intensity of } \\
\text { importance }\end{array}$ \\
\hline Equally important & 1 \\
\hline Moderately more important & 3 \\
\hline Strongly more important & 5 \\
\hline Very strongly more important & 7 \\
\hline Extremely more important & 9 \\
\hline Intermediate values $2,4,6,8$ & \\
\hline
\end{tabular}

Application of AHP method can be explained in four steps:

1. Setting a hierarchical model of decision problems in order with goal on the top criteria and subcriteria at lower levels, and alternatives at the bottom of the model.

2. At each level of hierarchical structure each elements of the structure are compared in pairs, whereby the decision makers express their preferences with the help of appropriate scale which has 5 degrees and 4 sub-degrees of verbally described intensities and the corresponding numerical values for them in the range from 1 to 9 .

3. Local priorities (weights) of criteria, subcriteria and alternatives at same hierarchical structure level are calculated through appropriate mathematical model and afterwards they are synthesized in total priorities of alternatives.

The rough decision matrix is normalized by taking the following actions:

- calculation of sums of columns $s j(k), 1 \leq j$ $\leq m$ which are written on an extra line;

- division of each element $\operatorname{dij}(k), 1 \leq i, j \leq m$ to the sums of its columnsj $(k)$; 
- calculation of consequences (performances), as averages of elements on each line, which are written in an extra column

$p_{i}^{(k)}=\frac{1}{m} \sum_{j=1}^{m} \frac{d_{i j}^{(k)}}{s_{j}^{k}} \quad 1 \leq i \leq m$

Table 2. Rough decision matrix

(Calculation of sums on columns)

\begin{tabular}{|c|c|c|c|c|}
\hline \multicolumn{5}{|c|}{ Rough decision matrix $\boldsymbol{D}^{(k)}$} \\
\hline Alternative & $\mathrm{A}_{1}$ & $\mathrm{~A}_{2}$ & $\ldots$ & $\mathrm{A}_{\mathrm{m}}$ \\
\hline $\mathrm{A}_{1}$ & $\mathrm{~d}_{11} 1^{(\mathrm{k})}$ & $\mathrm{d}_{12^{(\mathrm{k})}}$ & $\ldots$ & $\mathrm{d}_{1 \mathrm{~m}}{ }^{(\mathrm{k})}$ \\
\hline $\mathrm{A}_{2}$ & $\mathrm{~d}_{21}{ }^{(\mathrm{k})}$ & $\mathrm{d}_{22}{ }^{(\mathrm{k})}$ & $\ldots$ & $\mathrm{d}_{2 \mathrm{~m}}{ }^{(\mathrm{k})}$ \\
\hline$\ldots$ & $\ldots$ & $\ldots$ & $\ldots$ & $\ldots$ \\
\hline $\mathrm{A}_{\mathrm{m}}$ & $\mathrm{d}_{\mathrm{m} 1}{ }^{(\mathrm{k})}$ & $\mathrm{d}_{\mathrm{m} 2}{ }^{(\mathrm{k})}$ & $\ldots$ & $\mathrm{d}_{\mathrm{mm}}{ }^{(\mathrm{k})}$ \\
\hline $\begin{array}{c}\text { Sums of } \\
\text { columns }\end{array}$ & $s_{1}^{k}{ }^{m}$ & $s_{2}^{k}{ }^{m}$ & & $s_{m}^{k}{ }^{m}$ \\
& $=\sum_{i=1}^{m} d_{i 1}^{k}$ & $=\sum_{i=1}^{m} d_{i 2}^{k}$ & & $=\sum_{i=1}^{m} d_{i m}^{k}$ \\
\hline
\end{tabular}

Dividing each element and obtaining the normalized matrix

Table 3. Normalized matrix

\begin{tabular}{|c|c|c|c|c|}
\hline \multicolumn{6}{|c|}{ Normalized matrix $\boldsymbol{D}^{(\boldsymbol{k})}$} \\
\hline Alternative & $\mathrm{A}_{1}$ & $\mathrm{~A}_{2}$ & $\ldots$ & $\mathrm{A}_{\mathrm{m}}$ \\
\hline $\mathrm{A}_{1}$ & $\mathrm{~d}_{11^{(\mathrm{k})} /}$ & $\mathrm{d}_{12}{ }^{(\mathrm{k})} /$ & $\ldots$ & $\mathrm{d}_{1 \mathrm{~m}^{(\mathrm{k})} /}$ \\
& $\mathrm{s}_{1}{ }^{(\mathrm{k})}$ & $\mathrm{s}_{2}{ }^{(\mathrm{k})}$ & & $\mathrm{s}_{\mathrm{m}}{ }^{(\mathrm{k})}$ \\
\hline $\mathrm{A}_{2}$ & $\mathrm{~d}_{21}{ }^{(\mathrm{k})} /$ & $\mathrm{d}_{22}{ }^{(\mathrm{k})} /$ & $\ldots$ & $\mathrm{d}_{2 \mathrm{~m}^{(\mathrm{k})} /}$ \\
& $\mathrm{s}_{1}{ }^{(\mathrm{k})}$ & $\mathrm{s}_{2}{ }^{(\mathrm{k})}$ & & $\mathrm{s}_{\mathrm{m}}{ }^{(\mathrm{k})}$ \\
\hline$\ldots$ & $\ldots$ & $\ldots$ & $\ldots$ & $\ldots$ \\
\hline $\mathrm{A}_{\mathrm{m}}$ & $\mathrm{d}_{\mathrm{m} 1}{ }^{(\mathrm{k})} /$ & $\mathrm{d}_{\mathrm{m} 2}{ }^{(\mathrm{k})} /$ & $\ldots$ & $\mathrm{d}_{\mathrm{mm}}{ }^{(\mathrm{k})} /$ \\
& $\mathrm{s}_{1}{ }^{(\mathrm{k})}$ & $\mathrm{s}_{2}{ }^{(\mathrm{k})}$ & & $\mathrm{s}_{\mathrm{m}}{ }^{(\mathrm{k})}$ \\
\hline Sums of columns & 1 & 1 & $\ldots$ & 1 \\
\hline
\end{tabular}

Using the score column, the hierarchy of the decision alternatives is obtained: the decision means the selection of the alternative with the highest score.

Table 4. Performance matrix

\begin{tabular}{|c|c|c|c|c|c|}
\hline \multicolumn{6}{|c|}{ Final matrix $D$-performance matrix } \\
\hline \multirow{2}{*}{$\begin{array}{l}\text { Factor } \\
\text { weights }\end{array}$} & \multicolumn{4}{|c|}{ Decision factors } & \multirow{2}{*}{$\sum_{i=1}^{n} p_{i}^{(c)}=1$} \\
\hline & $\mathrm{P}_{1}{ }^{(\mathrm{C})}$ & $\mathrm{P}_{2}(\mathrm{C})$ & $\ldots$ & $\mathrm{P}_{\mathrm{n}}{ }^{(\mathrm{C})}$ & \\
\hline $\begin{array}{c}\text { Decision } \\
\text { alternatives }\end{array}$ & $\mathrm{C}_{1}$ & $\mathrm{C}_{2}$ & $\ldots$ & $\mathrm{C}_{\mathrm{n}}$ & $\begin{array}{l}\text { Weighted Sums } \\
\text { (general score) }\end{array}$ \\
\hline $\mathrm{A}_{1}$ & $\mathrm{p}_{1}(1)$ & $\mathrm{p}_{1}(2)$ & $\ldots$ & $\mathrm{p}_{1}(\mathrm{n})$ & \\
\hline $\mathrm{A}_{2}$ & $\mathrm{p}_{2}(1)$ & $\mathrm{p}_{2}(2)$ & $\ldots$ & $\mathrm{p}_{2}(\mathrm{n})$ & \\
\hline$\cdots$ & & & $\cdots$ & & \\
\hline $\mathrm{A}_{\mathrm{m}}$ & $\mathrm{p}_{\mathrm{m}}^{(1)}$ & $\mathrm{p}_{\mathrm{m}}(2)$ & $\ldots$ & $\mathrm{p}_{\mathrm{m}}^{(\mathrm{n})}$ & ${ }^{s_{m}}=\sum_{i=1}^{n} p_{i}^{(c)} p_{m}^{i}$ \\
\hline
\end{tabular}

4. Implementation of the sensitivity analysis for final decisions

\section{Experimental Results and Discussion}

If we speak of bioeconomy we get to both the domain of biotechnologies as well as to that of modern technologies. By the enforcement and rapid spread of Information and Communication Technologies we have a more intensified wish to understand how those modern technologies might be applied in the main sectors of economy for sustainable country development. It is more and more obvious that integration of information and communication technology is essential to accelerate the social-economic development especially by modernizing Romanian agriculture.

Therefore the challenge for implementation of innovative strategies, should allow the development of e-agriculture to avoid delays that can increase the discrepancy between the rural and the urban development. In this respect, same preconditions to use the technologies of communication and information in agriculture are established in eservice delimitation, developing possible technological platforms or channel diffusion and identification for some tangible benefits are necessary conditions bet not sufficient for the development of Romanian e-agriculture. There is a need to aggressively promote valuable creation added to the delivery service of eagriculture. The major force behind the long term demand for e-agricultural services will come also by using accessible platforms. By placing in the centre of e-agricultural development, the final user's key needs, the success in future is essential

An excellent example of good practice of using new technologies in agriculture and farming is Sweden, and this, because of the place Sweden occupies in the implementation of information technology and communications even in rural areas, number one in Europe and number two in the world after the United States. In the northern Europe is recorded the biggest dynamics in Europe of numbers for robots use in the farms. For examples the old technology requires a man to wash and fix milking machines. Claims of expertise were increasingly larger every year, which is why there was a need for an alternative. As a result of accessing the European project milking robots are used more and more often. A robot can handle 60-65 cows, and it costs 1 million Sweden Kronors /piece. The new technology 
system monitors each cow's milk, food, the number of milking per day, how much time has passed since the last milking, whether it is in fertile period if it is pregnant, if it is ill or what diseases it had, how old it is.

During the milking, the quantity of milk obtained from each nipple is measured and is compared by the computer with the average. Moreover the flow is measured and when it decreases, that robot is stopped and the nipple released.

The milk is pumped through pipes with air pressure into the main tank and samples are taken. These are sent to a laboratory in another city for testing, and the result is sent back over the Internet.

In more and more farms that own or work land are machines and tractors that use GPS system with a maximum error of $2 \mathrm{~cm}$ through satellites.

In the first instance employees stated they did not need this technology, but when the satellites are off for a few hours they complain that it was easier with GPS. Tractor keeps one direction, line, the GPS controlling and recording everything. When they sprayed the crops they have to keep a distance from the neighbours, sources of water, ditches between and all this processed is controlled by the satellite.

If errors are detected in the robotic milking system overnight (i.e. a feeder is blocked) only in case of major alarms the farmer or employee who was entered into the database of the computer responsible for that night is called and if he does not answer the others on the list follows.

The study shows also that from the perspective of the rural population the government is expected to do more to implement the digital economy in this environment thereby trying to reduce the digital divide.

To minimize the negative impact we have in view the investment of governments in developing services for the use of the Internet and the support infrastructure necessary for data traffic, satellites, Internet connection, phone services including subsidies for the necessary infrastructure to give GSM and $3 \mathrm{G}$ signal the rural areas.

We must not leave aside the most important resource to back the development namely the human capital who works for the mobile phones and computers, specialists to develop this content, electrician engineers to fight for the spreading of revolution technology regarding information and communication within the rural areas.

It is imperative to solve the problem regarding the access in the rural area of the information and communication technology and so modern agriculture will have a positive impact on the sustainable development of the continent.

From this outlook we believe it is very important to study the theme of competitive advantage within the rural environment by adopting modern information and communication technology and as an important objective that may be a chance in order to surpass the present situation.

The objectives of the EU are far from being attained regarding the dynamics of using the internet in the rural area and Romania lags far behind. But an increase of this dynamics is to be taken into account [9]. There is a strong connection between the increase in the number of Internet users in the rural area and the strategies of the companies that extend their business in online environment and start to give a greater attention to the rural both from consumers' and future employees' perspective, in this respect cutting down cost.

During the following priorities for rural development should go towards stimulating innovation and knowledge base in rural areas, strengthening the links between agriculture, research and innovation (e-agriculture), and promote vocational training in agriculture. All this is added to increase the competitiveness of agriculture and farm viability by facilitating generational renewal in agriculture [11].

According to the International Union of Telecommunication, a third of the world population has access to the internet while the digital gap is decreasing, estimating that one billion people live by agriculture and lack any kind of connection with information and communication technology [10]. I mention it in a special way as it represents a problem for the development of agriculture in Romania because farmers how live in the rural area are not endowed with services necessary for the technology of information and communication.

By using technology information and communication to promote the developing of agriculture, there are extraordinary economic social benefits and new opportunities to transform the means of existence for poor agricultural communities. Same are: food 
security that comes from the productivity of harvests and animal farms, improvement of access to national and global markets, improvement in delivery of rural financial service cutting costs in transactions, rapid methods of communication decision taking to manage the farm.

By using the technology of information and communication in agriculture and rural development will have a significant contribution both at a local, regional, national and international level.

Even if this technology was used in agricultural areas by the developed states years ago (precision agriculture, electronic actions, negotiations through an online platform) they were accelerated during the last 5 or 6 years, with a sudden growth in researching the opportunities offered by those technologies for the farmers, farms, governments as well as were governmental organizations for increase in the level of lining and state development.

The strategic information can be traded on web platforms in due time and include tariff data for the product, weather reports ,pests and surveillance for the disease, market assessment, change in supplying conditions for the products, market availability.

We have to highlight the importance of having more subjects related to Information and Communication Technologies that should be integrated into the national educational curriculum, because education is essential to the success of e-agriculture and sustainable rural development.

Coordination and integration of agricultural developments at national, regional and global levels is demonstrated by the flow of information and content of the development landscape that will stimulate agricultural development worldwide.

The areas studied are being presented in Figure 1,2 and 3.

The factors to be taken into consideration for the assessment of the new technologies in the rural area are:

- TV subscriptions;

- mobile phones number;

- landline phone subscribers;

- landline subscribers through the local cable;

- Internet subscriptions.

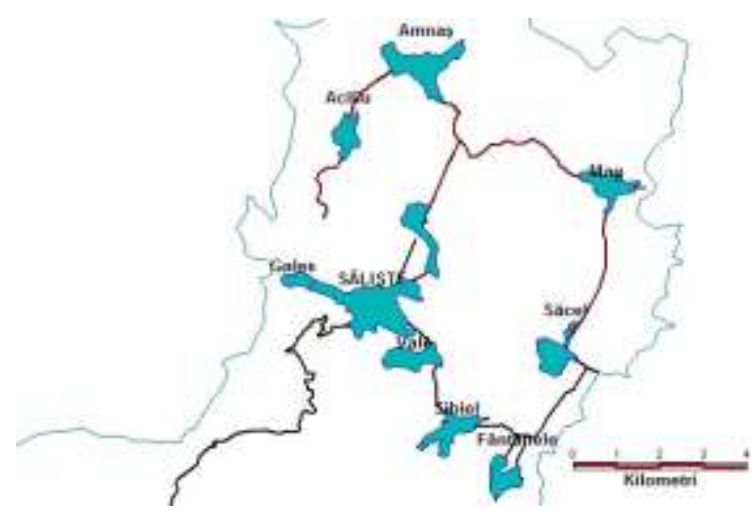

Figure 1. Saliste region

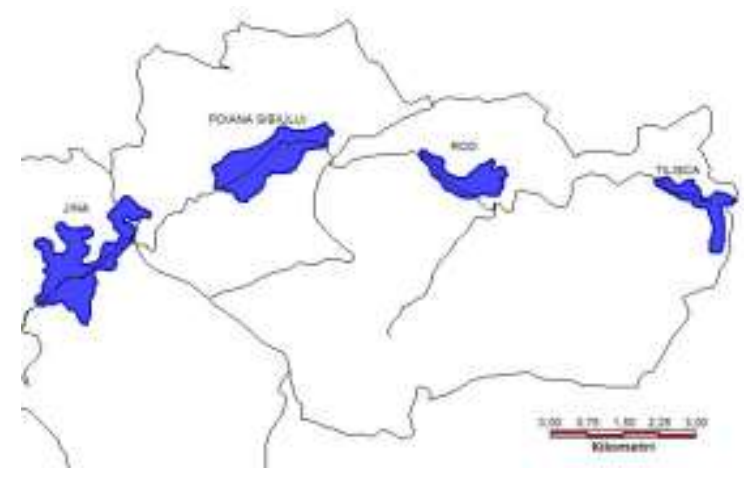

Figure 2. Poiana Sibiului region

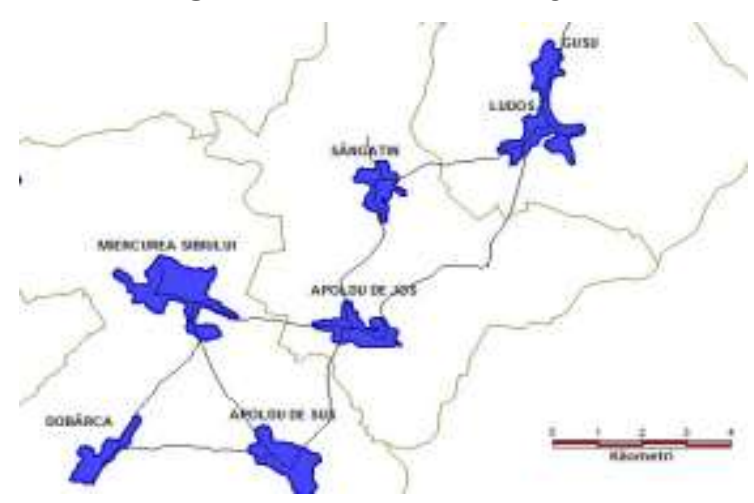

Figure 3. Apoldu region

We want to determine the importance of each factor in assessing the new technologies in the rural area. In this respect we will make use of the AHP method. We establish the importance of the rural location according to factors that we randomly take into consideration: number of inhabitants, number of buildings, income per inhabitants, agricultural output.

We work out the matrix of the importance regarding each place.

We take into consideration, Saliste as being the most important one because of a larger number of population and economic power compare to the other places situated nearby. Next place in this hierarchy is occupied by Poiana Sibiului village, following same criteria. 
Table 5. The importance of rural locations

\begin{tabular}{|c|c|c|c|c|c|c|}
\hline & $\begin{array}{c}\text { Apoldul } \\
\text { de Jos }\end{array}$ & $\begin{array}{c}\text { Apoldul } \\
\text { de sus }\end{array}$ & Jina & PoianaSibiului & Tilisca & Saliste \\
\hline Apoldu de Jos & 1 & 0.5 & 0.33 & 0.2 & 0.33 & 0.2 \\
\hline Apoldu de Sus & 2 & 1 & 0.33 & 0.25 & 0.5 & 0.25 \\
\hline Jina & 3 & 3 & 1 & 0.5 & 3 & 0.33 \\
\hline PoianaSibiului & 5 & 4 & 2 & 1 & 3 & 1 \\
\hline Tilisca & 3 & 2 & 0.33 & 0.33 & 1 & 0.33 \\
\hline Saliste & 5 & 4 & 3 & 2 & 3 & 1 \\
\hline
\end{tabular}

We calculate the matrix of the weight regarding each place according to its importance.

Table 6. The weight of the rural location

\begin{tabular}{|c|c|}
\hline Apoldu de Jos & 0.044942 \\
\hline Apoldu de Sus & 0.0646 \\
\hline Jina & 0.171474 \\
\hline Poiana Sibiului & 0.275634 \\
\hline Tilisca & 0.098438 \\
\hline Saliste & 0.344911 \\
\hline
\end{tabular}

Looking at this table number 6 , we notice that Saliste have a bigger weight and is followed by Jina village.

We make the matrix of the factors for Apoldul de Sus, Saliste and Apoldul de Jos, by comparing them in pairs.

Table 7. The Matrix of Factors in three rural locations

\begin{tabular}{|c|c|c|c|c|c|}
\hline & TV & $\begin{array}{c}\text { Phone } \\
\text { Mobile }\end{array}$ & $\begin{array}{c}\text { Tele } \\
\text { phone }\end{array}$ & $\begin{array}{c}\text { Computers / } \\
\text { Laptops }\end{array}$ & Internet \\
\hline $\begin{array}{c}\text { TV } \\
\text { Subscribers }\end{array}$ & 1 & 0.33 & 2 & 0.33 & 0.25 \\
\hline Phone Mobile & 3 & 1 & 3 & 0.33 & 0.33 \\
\hline Telephone & 0.5 & 0.33 & 1 & 0.25 & 0.2 \\
\hline $\begin{array}{c}\text { Computers / } \\
\text { Laptops }\end{array}$ & 3 & 3 & 4 & 1 & 2 \\
\hline $\begin{array}{c}\text { Internet } \\
\text { Subscribers }\end{array}$ & 4 & 3 & 5 & 0.5 & 1 \\
\hline
\end{tabular}

We make the matrix of the factors regarding the new technologies Poiana Sibiului, Tilisca, Jina, by comparing them in pairs. This time the data of assessment regarding the factors for the new technologies change.

Table 8. The Matrix of Factor in three rural mountain locations

\begin{tabular}{|c|c|c|c|c|c|}
\hline & TV & $\begin{array}{c}\text { Phone } \\
\text { Mobile }\end{array}$ & $\begin{array}{c}\text { Tele } \\
\text { phone }\end{array}$ & $\begin{array}{c}\text { Compu/ } \\
\text { Laptops }\end{array}$ & $\begin{array}{c}\text { Inter } \\
\text { net }\end{array}$ \\
\hline TV & 1 & 0.14 & 2 & 0.33 & 0.2 \\
\hline $\begin{array}{c}\text { Phone } \\
\text { Mobile }\end{array}$ & 7 & 1 & 5 & 3 & 2 \\
\hline Telephone & 0.5 & 0.2 & 1 & 0.25 & 0.2 \\
\hline $\begin{array}{c}\text { Computers } \\
\text { Laptops }\end{array}$ & 3 & 0.33 & 4 & 1 & 2 \\
\hline Internet & 5 & 0.5 & 5 & 0.5 & 1 \\
\hline
\end{tabular}

The most important factor, we consider it to be mobile telephone and the internet.

We calculate the weight of the factors regarding the new technologies for each of the three places. We obtain the matrix of the weight for factors that influence the introduction of new technologies in the rural area in all 6 places/ villages that we take into consideration and we multiply with the matrix of the weight regarding the rural places.

We get the weight of each factor that influences the new technologies in the rural area for all 6 places taken into consideration.

Table9. The weight of each factor that influences the new technologies in the rural area

\begin{tabular}{|l|r|}
\hline TV Subscribers & 0.073601 \\
\hline Phone Mobile & 0.307735 \\
\hline Telephone & 0.053289 \\
\hline Computers / Laptops & 0.301904 \\
\hline Internet Subscribers & 0.263469 \\
\hline
\end{tabular}

The results obtained here, show that mobile telephony has a bigger importance (weight) and the computers and laptops are next in this hierarchy. The study reveals that the internet users are an important factor but we have to take in consideration even more the number of laptops computer and mobile phones. By realizing a better integration of modern information technology into the rural area the social-economic effects will prevail, and the competitive advantage of these areas will be assured.

\section{Conclusions}

Despite the progress that has been made in rural development and agriculture, there are still many difficulties to be overcome. Without joint action by the state local actors of rural communities, this development will suffer and delay the harmonious development of the country. 
Application on a wider scale and more effective use of digital technologies will thus enable Europe to address fundamental challenges and will provide Europeans with a better quality of life, due better healthcare services, more effective transport solutions, a cleaner environment, new possibilities of communication and easier access to public services and cultural content [12].

Development of high-speed Internet networks today has a revolutionary impact similar to that of the power and transport networks a century ago. Europe is still a patchwork of national online markets, and Europeans cannot take advantage of a digital single market due to problems that can actually be solved.

Commercial and cultural content and services need to be able to move freely across borders, and this objective could be achieved by eliminating regulatory barriers and facilitating electronic billing and payment transactions, to resolve disputes, as well as consumer confidence. This study is intended to achieve an increase in market interoperability based on local, regional, European and then global.

Out of all the data obtained, it is obvious that the most important factor is the mobile phone, and this is mostly due to its importance in the 3 mountain villages Jina, Poiana Sibiului and Tilisca. Second place as importance is to take into consideration the computer and the subscription on the internet.

\section{REFERENCES}

1. BANCIU, D., R. M. BONCEA, C. I. ROTUNA, M. ANGHEL, Bringing EU Entrepreneurs together through Crossborder Services: SPOCS - a Case Study, Studies in Informatics and Control, ISSN 1220-1766, vol. 21 (3), 2012, pp. 303-314

2. BANCIU, D., University Libraries within the Digital Environment Promoted by the i2020 Strategy, Innovation within Libraries, Editura Universitatii Transilvania, Brasov, vol.7, 2011, pp. 7-8.

3. PORTER, M. E., The Competitive Advantage of Nations, Harward Business Review, March 1990, pp. 3.
4. COVACI, B., A. - G. STRATEANU, A. T. BOGDAN, V. SIMION, D. L. DIACONESCU, D. TEPUS, S. CHELMU, D. GABOR, E-banking Products and Services for Agribusiness based Ecoeconomy, with Ways "From the Farm to the Fork", in Forecasting the Developed and Developing Countries on Period 20202050-2100, No 2009/156, OsterreichishRumanischer Akademischer Verein, 2009, pp. 23-24.

5. GEORGESCU-ROEGEN, N., Legea entropiei şi procesul economic, Editura Politică, Bucureşti, (in care by Aurel Iancu, 1979), pp. 17-18.

6. HAWKEN, P., Blessed Unrest, Viking Press, New York, 2007, pp. 29-30.

7. HERMANN, B. G., C., KROEZE, W., JAWJIT, Assessing Environmental Performance by Combining Life Cycle Assessment, Multi-criteria Analysis and Environmental Performance, Journal of Cleaner Production, vol. 15, no. 18, 2007, pp. 1787-1796.

8. MALIKI, A., G., OWENS, D. BRUCE, Combining AHP and TOPSIS Approaches to Support Site Selection for a Lead Pollution Study, 2nd International Conference on Environmental and Agriculture Engineering, IPCBEE vol. 37 C (2012) IACSIT Press, Singapore, 2012.

9. SAATY, T. L., The Analytic Hierarchy Process, McGraw-Hill, New York, 1980.

10. POPESCU, C-TIN, Viața ca optimism tragic. Perspectiva ecolonomică, Editura ASE, 2011, pp. 232-233.

11. MAUMBE, B. M., E-Agriculture and EGovernment for Global Policy Development: Implications and Future Directions, Kentucky University, USA, 2009, pp. 127-128.

12. SERBU, R., S. BORZA, B. MARZA, BioEco-Analysis for Risk Factors using GIS Software, International Journal of Computers, Communications \& Control, vol. 8, no. 2, 2013, pp. 78-79. 